\title{
KOODIVAHETUSEST PETERBURI VANEMA PÕLVKONNA EESTLASTE KEELEKASUTUSES
}

\author{
Lea Jürgenstein \\ Tartu Ülikool
}

\begin{abstract}
Kokkuvõte. Artikkel keskendub Peterburi eestlaste vanema põlvkonna keelekasutusele. Eesmärgiks on kirjeldada koodivahetust, selle funktsioone ja ilmnemist vestluses ükskeelse eestlasega. Koodivahetusel on vestluses metafooriline roll; sageli kasutavad kõnelejad koodivahetust kontekstualiseerimise vahendina ja annavad märku oma hoiakutest. Teisalt võib see olla ka suhtlusstrateegia, mille abil keelejuhid otsivad vestluskaaslaselt abi ununenud sõna leidmisel, püüavad teadlikku koodivahetust ära hoida või täpsustavad öeldut. Et koodivahetus on oluline leksikaalsete laenude vahendaja, vaadeldakse artiklis ühe- ja paarisõnalise koodivahetuse ja laenu vahekorda.
\end{abstract}

Märksõnad: diasporaa, laen, suhtlusstrateegia, kakskeelsus, eesti keel

\section{Sissejuhatus}

Kahe keele vahelduv kasutamine ehk koodivahetus on kakskeelsete kõnelejate keelekasutuse silmatorkavamaid ilminguid. Vanemad uurijad (nt Weinreich 1953, Haugen 1953) on tõdenud, et koodivahetus võib peegeldada kõneleja keelekompetentsuse puudujääke; nüüdisaegsetes lähenemistes tuuakse välja selle nähtuse sotsiaalne aspekt (Gumperz 1982, Kalliokoski 1995), millega kõneleja annab mõista oma hoiakutest ja valikutest. John Gumperz on koodivahetust määratlenud kui diskursiivset vahendit (hiljem täpsustab seda terminitega situatiivne ja metafooriline koodivahetus), mis kätkeb eneses kõneleja sotsiokultuurilisi hoiakuid (Gumperz 1982).

Artikli esimeses osas tutvustatakse Peterburi eestlaste kogukonda ja uurimuse keelejuhte, järgmistes osades keskendutakse eesti ja vene keele vahelduvale kasutusele Peterburi eestlaste eestikeelses vestluses. Täpsemalt on uurimuse keskmes teadliku koodivahetuse peamised funktsioonid: mis tingimustel 
ja kuidas kakskeelsed kõnelejad lähevad vestluse põhikeelelt (eesti keelelt) üle teisele keelele (vene keelele). Artikli eesmärgiks on käsitleda koodivahetuse ilminguid ja funktsioone ning nende tõlgendamisvõimalusi Peterburi vanema põlvkonna eestlaste keeles. Vene keele valikul on eestikeelses vestluses kahetine roll: see võib olla teadlik keeleline käitumine, teisalt aga võib keelevahetus olla spontaanne.

\section{Eestlased Peterburis}

\subsection{Peterburi ja Loode-Venemaale väljarändajad}

19. sajandi esimesel poolel algas Eestis talurahva väljarändamine, mille põhjuseks oli talupoegade soov maad saada või linnades elatist teenida (Pullat 2004: 37). Kodumaalt lahkumise eelduseks said Tsaari-Venemaa sisepoliitilised muudatused, hakkasid toimima reformid, mis lubasid talupoegadel kodukohast mujale siirduda. Väljarändamine hoogustus 1860. aastatel, mil sihtkohaks said lisaks Samaara ja Tauria kubermangule (Kulu 1992: 17, Pullat 2004: 37) Loode-Venemaa alad ning Peterburi, millest sai aastate jooksul eestlaskonna suurem linnakeskus. Väljarändamine impeeriumi pealinna ja selle lähikonda jätkus kuni 20. sajandi alguseni.

Esialgu ühendas Peterburis oma elu sisse seadnud eestlasi luteri kogudus, kellele peeti teadaolevalt eestikeelseid jumalateenistusi alates 1787. aastast (Mahtina 2009: 8). Alates 1894. aastast hakkas Peterburis tegutsema eestikeelne õigeusu kogudus. Raimo Pullati hinnangul kuulus nendesse kahte kogudusse umbes pool Peterburi eestlaskonnast (Pullat 2004: 86-87). Luteri kirikud, palvemajad ja eesti koolid tegutsesid ka mitmes suuremas eestlaste asunduses, näiteks Luugas, Gattšinas ja Oudovas (Nigol 1918).

Järsud muudatused tabasid Peterburi eestlaste elu 1917. aasta revolutsiooni järel ja Eesti Vabariigi loomisega. Eesti Vabariiki opteeris suur osa Venemaal elanud eestlastest. Hill Kulu (1992: 27) oletab, et suur osa 40000 optandist võis pärineda Peterburi linnast või sellega piirnevatelt aladelt. 1926. 
aasta rahvaloenduse andmetel elas Leningradi kubermangus kokku 66333 eestlast, seejuures Peterburi linnas elas rahvaloenduse andmeil 15847 eesti rahvusest inimest, kellest 10 970-le oli eesti keel emakeeleks (Kulu 1992: 29).

1918. aastal suleti Peterburis Eesti Haridusselts ja enamik teisi ühinguid, üksnes kirik sai tegutsemist jätkata. Esialgu jäid puutumata ka eesti koolid maapiirkondades (Raag 1999: 52). Revolutsioonijärgses Peterburis hakkas 1919. aastast tegutsema eesti töörahva ülikool, kus valmistati ette eesti koolide õpetajaid; 1921. aastal asutati Lääne Vähemusrahvuste Kommunistlik ülikool, millel oli ka eesti osakond (Raag 1999: 54, Moosberg 1986: 27). Enne stalinlike repressioonide algust (kuni 1936. aastani) ilmus Peterburis ka mitu eestikeelset ajalehte ja tuhatkond raamatut (Raag 1999: 54).

Eesti keelt kasutas emakeelena enamik Nõukogude Liidu maapiirkondades elanud eestlastest (Kulu 1992: 43), kuid riigi sisepoliitika kujunes üsna kiiresti rahvusgruppe hävitavaks. Massiliste repressioonide aastad aga muutsid eestlaste eluolu täielikult: kõik eestikeelsed õppeasutused läksid üle vene keelele, rahvuslikud seltsid, ajalehed ja kirjastused ja ühingud suleti.

Pärast Teist maailmasõda, kui kahe riigi vaheline piir avati, hakkasid paljud Peterburi ja lähikonna eestlased otsima Eestis elavaid sugulasi. Perede kontaktid suudeti (osaliselt) taasluua ja läbikäimine sugulaste vahel sagenes, mis aitas kaasa ka eesti keele oskuse hoidmisele. Osa eestlastest siirdus ka alaliselt Eestisse elama (Jürgenstein ja Rootalu 2011).

Samas algas ka vastupidine ränne: nõukogude suurlinnade kõrgkoolides oli liiduvabariikide noortele ette nähtud teatud arv kohti, mistõttu 1950. aastatest suundus ka hulk Eesti keskkoolilõpetajaid Venemaale õppima. Eesti haritlasi sattus 1950. aastatel Leningradi ja selle lähistele ka sundkorras, kui Tallinna Polütehnilise Instituudi lõpetanuid suunati Venemaale tööle. Osa noil aastail Peterburi ja selle lähikonda tulnud noortest lõi seal pere ja jäi alaliselt võõrsile elama. Hilisematel aastatel on Peterburi või selle lähilinnadesse asunud elama ka Eestist küüditatud, kellel vabanemisel keelati algul Eestisse naasta. 


\subsection{Keelejuhtidest ja materjalist}

Laiema uurimuse keelejuhtideks on Peterburis elavad eestlased, keda võib jagada kaheks rühmaks: põlisteks (19. sajandi lõpust kuni 20. sajandi teise kümnendini Venemaale siirdunud väljarändajate järeltulijad) ja esimese põlvkonna Peterburi eestlasteks (pärast II maailmasõda Peterburi elama asunud eestlased). Käesolev artikkel on osa ulatuslikumast uurimusest, mille tarvis on salvestatud intervjuusid 16 keelejuhiga mõlemast rühmast. Siinne kirjutis keskendub peamiselt kümne põlise Peterburi eestlase keelekasutusele.

Tabel 1. Keelejuhtide andmestik. Põlised Peterburi eestlased.

\begin{tabular}{|c|c|}
\hline Kood & Kirjeldus \\
\hline 1N92 & $\begin{array}{l}\text { sündinud Peterburi lähistel eesti peres, emapoolsed vanava- } \\
\text { nemad Eestist välja rännanud 19. sajandi keskel; isa sündinud } \\
\text { Eestis, lapsena koos vanematega välja rännanud. Õppinud } \\
\text { eestikeelses algkoolis. Kõrgharidus, töötanud teadusasutuses. }\end{array}$ \\
\hline $1 \mathrm{~N} 86$ & $\begin{array}{l}\text { sündinud Peterburi lähistel eesti peres, emapoolsed vanava- } \\
\text { nemad Eestist välja rännanud 1871. aastal, isa sündinud Ees- } \\
\text { tis. Õppinud eestikeelses algkoolis. Kõrgharidus, töötanud } \\
\text { teadusasutuses. }\end{array}$ \\
\hline $1 \mathrm{~N} 82$ & $\begin{array}{l}\text { sündinud Peterburi lähistel eesti peres, ema sündinud Ees- } \\
\text { tis ja lapsena koos vanematega Venemaale välja rännanud; } \\
\text { isapoolsed vanavanemad Eestist välja rännanud 19. sajandi } \\
\text { lõpul. Keskeriharidus. }\end{array}$ \\
\hline $1 \mathrm{M} 80$ & $\begin{array}{l}\text { sündinud Peterburi lähistel eesti peres, isapoolsed vanavane- } \\
\text { mad Eestist välja rännanud, ema pere asus Venemaale elama } \\
\text { oktoobrirevolutsiooni künnisel. Elas II maailmasõja ajal } \\
\text { lühikest aega Eestis. Keskeriharidus. }\end{array}$ \\
\hline 1N77 & $\begin{array}{l}\text { sündinud Peterburi lähistel eesti peres, vanavanemad Ees- } \\
\text { tist välja rännanud 19. sajandi lõpul. Elas II maailmasõja ajal } \\
\text { lühikest aega Eestis. Keskeriharidus. }\end{array}$ \\
\hline $1 \mathrm{~N} 76$ & $\begin{array}{l}\text { sündinud Peterburis eesti peres, vanavanemad Eestist välja } \\
\text { rännanud 19. sajandi lõpul. Kõrgharidus. }\end{array}$ \\
\hline 1N69 & $\begin{array}{l}\text { sündinud Venemaal eesti peres, õppinud vene koolis, lühi- } \\
\text { kest aega elanud Eestis, õppinud venekeelses keskkoolis. } \\
\text { Kõrgharidus (venekeelne), töötanud teadusasutuses. }\end{array}$ \\
\hline
\end{tabular}




\begin{tabular}{|l|l|}
\hline 1N66 & $\begin{array}{l}\text { sündinud Peterburi lähistel eesti peres, isa asus Venemaale } \\
\text { 20. sajandi alguses, ema pärit Venemaa eestlaste perest. Elas } \\
\text { lapsena lühikest aega Eestis. Kõrgharidus. }\end{array}$ \\
\hline 1N32 & $\begin{array}{l}\text { sündinud Venemaal eesti-vene segaperekonnas, elanud lühi- } \\
\text { kest aega Eestis, õppinud venekeelses koolis ja kõrgkoolis, } \\
\text { hiljem eestikeelses kraadiõppes. Kõrgharidus. }\end{array}$ \\
\hline 1M32 & $\begin{array}{l}\text { sündinud eesti-vene segaperekonnas, õppinud venekeelses } \\
\text { koolis. Kõrgharidus (eestikeelne). }\end{array}$ \\
\hline
\end{tabular}

Tabel 2. Keelejuhtide andmestik. Pärast II maailmasõda Venemaale ja Peterburi elama asunud keelejuhid.

\begin{tabular}{|l|l|}
\hline Kood & Kirjeldus \\
\hline 2N91 & $\begin{array}{l}\text { sündinud Eestis, Venemaale sattunud täiskasvanueas. Kesk- } \\
\text { haridus (eestikeelne). }\end{array}$ \\
\hline 2M71 & $\begin{array}{l}\text { sündinud ja õppinud Eestis, Peterburi sattunud täiskasvanu- } \\
\text { eas. Kõrgharidus (eestikeelne). }\end{array}$ \\
\hline 2N68 & $\begin{array}{l}\text { sündinud Eestis, Peterburi asunud elama täiskasvanueas. } \\
\text { Kõrgharidus (venekeelne). }\end{array}$ \\
\hline 2N67 & $\begin{array}{l}\text { sündinud Eestis, Peterburi asunud elama täiskasvanueas. } \\
\text { Kõrgharidus (venekeelne). }\end{array}$ \\
\hline 2N66 & $\begin{array}{l}\text { sündinud Eestis, lapsepõlves elanud lühikest aega Venemaal, } \\
\text { naastes õppinud Eestis eestikeelses koolis. Peterburi sattu- } \\
\text { nud täiskasvanueas. Kõrgharidus (venekeelne). }\end{array}$ \\
\hline 2N52 & $\begin{array}{l}\text { sündinud Eestis eesti-vene segaperekonnas, elanud Vene- } \\
\text { maal, kuid lapsepõlves suviti Eestis. Kõrgharidus. }\end{array}$ \\
\hline
\end{tabular}

Keelejuhtide valikul on lähtutud eeldusest, et eesti keel on nende esimene keel (lapsepõlvekodus kõneldud keel) ja keelejuht valdab seda vähemalt argivestluse tasemel.

Salvestused on tehtud 2009. a jaanuarist kuni 2011. a veebruarini lühemate ja pikemate vaheaegade järel. Materjal (ligikaudu 22 tundi audiosalvestisi) on kogutud peamiselt intervjuudena, küsimuste temaatika oli valdavalt personaalne info (päritolu, perekond, mälestused Peterburist ja esimesed kokkupuuted Eestiga, eestlaste kooskäimistest ja nüüdsest seltsielust). Usutluste tekstilõigud on suhteliselt pikad ja sarnanevad monoloogiga. Artiklis esitatud näitelausete juures on viide keelejuhile, 
kus number näitab, millise põlvkonna kõnelejaga on tegemist (1 - põliste väljarännanute järeltulijad; 2 - pärast II maailmasõda Peterburi elama asunud), $\mathrm{M}$ ja $\mathrm{N}$ vastavalt meest või naist ning viimane number keelejuhi vanust kõnelemise hetkel. Praegune eesti kogukond pole stabiilne, omavahel suheldakse kahes keeles, noorema põlvkonnaga paljudes perekondades pigem vene keeles, sest tegemist on segaperekondadega. Eesti keelt räägitakse eestlaste ringis - nii Peterburi eestlastega kui ka Eestis elavate sugulastega. Igapäevases suhtluses on aga kunagine esimene keel taandunud teisele kohale vene keele järel.

\section{Koodivahetus}

Koodivahetust ehk kahe (või enama) keele kasutamist vestluse või lausungi raames peetakse mitmekeelsuse üheks olulisemaks aspektiks. Keelte vaheldumine võib piirduda ühe sõna või lausekatkega, aga võib hõlmata ka kõnevooru või pikemaid lõike (Verschik 2004: 346, Viikberg 1989: 202).

Koodivahetuse uurimisega on tegeldud üle poole sajandi. 1953. aastal ilmunud teoses "Languages in contact" juhtis kakskeelsuse ja keelekontaktide uurimisega tegelnud Uriel Weinreich tähelepanu kakskeelsusele ja selle iseärasustele, tuues iseloomuliku joonena välja kahe keele vahelduvat kasutamist (Weinreich 1953: 1). Samal, 1953. aastal ilmus ka Einar Haugeni (1953) põhjalik käsitlus Ameerika Ühendriikides elavate norralaste keelekasutusest, milles autor kirjeldab üksikasjalikult keelekontakte ja kakskeelsust.

Nüüd, veidi enam kui pool sajandit hiljem, on huvi mitmekeelsuse vastu oluliselt suurenenud. Selle valdkonna uurimissuunad võib jagada kolme üksteist täiendavasse rühma: 1) süntaktilis-grammatiline, 2) pragmaatiline ja 3) sotsiolingvistiline suund (Pérez Casas 2008, aga ka Verschik 2004: 346 ja Praakli 2009: 22), mis on pakkunud mitmesuguseid koodivahetuse tõlgendusi. Süntaktilis-grammatiline suund on püüdnud sõnastada koodivahetuse piiranguid ja kujundada mudeleid (nt rektsiooni piirangu teooria ja maatrikskeele raamistiku mudel; täpsem üle- 
vaade Verschik 2004: 25-45, Sarhimaa 1999: 123-148), millega esialgu üritati anda universaalseid seletusi. Selline lähenemine on esitanud uurijatele väljakutseid nii tüpoloogiliselt sarnaste kui ka väga erinevate keelepaaride lähemaks vaatluseks. Sotsiolingvistilise ja grammatilise suuna uurijad on huvitunud koodivahetuse ja laenude eristamisest. Käsitlustest selgub, et nende kahe nähtuse vahel pole kindlat piiri, vaid neid tuleks vaadelda kontiinumina (Lauttamus 1992), samas kerkib laenude ja koodivahetuse eristamise juures esile tüpoloogiliselt väga lähedaste keelte vastastikuse mõjutamise küsimus, st kumma keele grammatika on domineeriv ja kuidas laenud sobituvad süsteemi fonoloogiliselt ja morfoloogiliselt. Pragmaatilise uurimissuuna fookuses on selgitada koodivahetuse rolli ja osatähtsust kommunikatsioonis, millest on lähemalt juttu artikli osas 2.1.

Eesti keeleteaduses on keelekontakte uuritud kahest aspektist: ühelt poolt on vaadeldud Eesti keeleruumis esinevat kakskeelsust ja koodivahetust (Verschik 2004, 2007 ja 2010; Zabrodskaja 2005, 2009), teisalt väliseestlaste keelevariante (Hennoste 2003: 223). Väliseesti keele vastu hakati Eestis huvi tundma 1960. aastatel, siis tehti uurimisretki Nõukogude Liidus elavate eestlaste juurde ja muu hulgas uuriti ka nende keelt. 1970.-1980. aastatel huvi jätkus, tulemuseks on mitu suuremat uurimust, nende hulgas Jüri Viikbergi kandidaaditöö ja artiklid Siberi eestlaste keelest (Viikberg 1989, 1997; Viikberg ja Vaba 1984) ning Tiina Kesseli diplomitöö (1981) Kaukaasia eestlaste keelest (Hennoste 2003: 235-237). Samal ajal tärkas huvi ka lääne pool elavate eestlaste ja nende keele vastu, peamiselt olid uurimisfookuses Rootsi eestlased; silmapaistvamateks tulemuseks on Aarand Roosi (1980) ja Raimo Raagi (1982) doktoritööd, mis käsitlesid Rootsi eestlaste sõnavara, morfoloogiat ja rootsi keele mõjusid (Hennoste 2003: 235). Kui seniste uurimuste põhitähelepanu oli asukohamaa sõnalaenudel ja grammatika mõjul, siis viimasel kümnendil on huvi keskmes kakskeelsus ja suulise keele iseärasused, seal hulgas ka koodivahetus. Kristiina Praakli doktoritöö (2009) käsitleb Soome eestlaste keelekasutust, Maarika Terali magistritöös (2007), kirjeldatakse muu hulgas kontekstisidusat koodivahetust ning Mari Allik analüüsib oma magistritöös (2002) noorte Rootsi eestlaste keelt. 


\subsection{Koodivahetus kui kontekstivihje}

Varasemad kakskeelsuse uurijad suhtusid koodivahetusse hinnanguliselt, pidades kahe keele segunemist kõneleja keeleliseks suutmatuseks (Weinreich 1953, Haugen 1953). Ehkki seesugune lähenemine on leidnud arvukalt kritiseerijaid, tõdevad koodivahetuse uurijad, et koodivahetuse üheks funktsiooniks on täita kõneleja keelekompetentsuse leksikaalseid ja grammatilisi puudujääke (Kalliokoski 1995: 4). Koodivahetuse pragmaatilisele küljele keskendunud uurijad (nt Gumperz 1982, Sarhimaa 1999) on toonud esile selle nähtuse sotsiaalset aspekti, kus arvestatakse kõnelejate sotsiaalse identiteedi, individuaalsete iseärasuste ja hoiakutega. Anneli Sarhimaa (1999: 125) toonitab koodivahetuse pragmaatilist iseloomu, viidates kakskeelsete kõnelejate isesugusele keelelisele kompetentsusele.

Koodivahetuse pragmaatilise uurimissuuna rajaja John Gumperz toob olulisena esile koodivahetuse metafoorilise rolli: keelte vahelduvas kasutamises peitub kontekstivihje, mis annab pragmaatilist ja sotsiaalset informatsiooni (Gumperz 1982: 59-99, samal teemal ka Kalliokoski 1995: 4-6 ja Verschik 2004: 35).

Pragmaatiline käsitlus vaatleb keelte vahelduvat kasutamist suhtluses; eestikeelsetes vastavasisulistes uurimustes keskendutakse koodivahetusele vestluse sees (Praakli 2001: 23, 2007: 20), analüüsimisel on kasutatud konversatsioonianalüüsi võtteid (Verschik 2001: 36, Praakli 2009: 23). Vestlus võimaldab vaadelda eri keelte kasutamist kontekstisidusalt, st koodivahetuses peitub vihje öeldu tõlgendamiseks (Auer 1992). Nii on koodivahetus üks kontekstivihje intonatsiooni, kõnetempo muutuse, pauside, rõhutamiste, köhatuse, naeru jt kõrval, millega antakse märku mingisugusest muutusest vestluse või lausungi käigus (Kalliokoski 1995: 3).

Pragmaatilisest seisukohast lähtunud John Gumperz liigendab koodivahetust situatsiooniliseks ja metafooriliseks. Esimene tuleneb muutusest vestlussituatsioonis (nt vestlusse liitub uus osaline või muutub vestluse teema), teine peegeldab vestluses osalejate hoiakuid. Klassikaks saanud uurimuses "Discourse strategies" toob Gumperz (1982: 75-82) välja kuus koodivahe- 
tuse funktsiooni, mis peegeldavad suhtluse kulgemist arvestavaid aspekte. Hilisemad uurijad on seda konversatsiooniliste funktsioonide loetelu täiendanud ja täpsustanud (lähemalt Zabrodskaja 2005: 70-75). Loeteludes on olulisel kohal tsiteerimine ja refereerimine, kordamised, sõnumi täpsustamine, adressaadi määratlemine või vestluse osalejaskonna muutumine või kõneleja rollivahetus, kõrvalmärkused ja teemavahetused.

Kakskeelse kõneleja puhul on koodivahetuse motiveerijaks teema, milles kõneleja tunneb ennast ühes keeles kindlamalt kui teises; samuti võib mõne valdkonna sõnavara olla teises keeles tuttavam ja esimeses keeles hoopis puududa (Viikberg 1989: 203). Siberi eestlaste näitel nimetab J. Viikberg sellisteks teemadeks igapäevast tööd, tänapäevaseid probleeme, noorte elu ja elukutseid.

Näide 1 pärineb eestikeelsest vestlusest, kõnelejateks kakskeelne keelejuht (märgitud K) ja intervjueerija (I). Keelejuht räägib, kuidas ta pensionile jäädes talviti suvilakrundi ostuks ja maja ehitamiseks raha teenis. Vestluse keeleks oli enne lindistust kokku lepitud eesti keel. Küsitleja jäi selle kokkuleppe juurde, vestluspartner aga vahetas keelt: esialgu tõi eestikeelsesse vestlusse üksikuid sõnu ja väljendeid (posudu myla, kafe), kuid „hoogu sattudes” libises järk-järgult üle vene keelele. Näitest nähtub, et kõnelejale on loomulikum (keelepärasem) loetleda oma töökohti ja tööülesandeid vene keeles, samuti kirjeldada selles keeles üleüldse kogu töötamist ja selle tagamaid.

Näide kinnitab ka väidet, et ühel koodivahetusjuhtumil võib olla samal ajal mitu funktsiooni: öeldu olulisuse rõhutamiseks kordab kõneleja öeldut kahes keeles, alguses eesti keeles (kõik, mis ma sain, talvel teenisin), repliigi lõpus vene keeles (mne den'gi byli dlja postroiki ètoi samoi na dače).

$\mathrm{K}$ : mina ehitasin oma maja ära (..) mina oma rahadega (..) kõik mis ma sain (.) talvel teenisin (..) posudu myla, pesin

1 Siin ja edaspidi litereeritud näidetes märgib (.) lühikest pausi, (..) pikemat pausi, <> valjemat hääletooni, ? tõusvat intonatsiooni küsimuse vormistamisel. 
põrandaid (..) kafe seal on see nuka peal metroo juures (.) kafe-moločnaja byla (.) i tam ja rabota(la), sudumoika (.) uborščitsa (..) i kem tol'ko ne rabotala (..) zimoi porabotaju (.) vesnoi uhažu (.) zimoi porabotaju (.) vesnoi uhažu (..) Mne den'gi byli dlja postroiki ètoi samoi na dače

I: Aga nü̈̈d te olete suvilas kõik suved?

$\mathrm{K}$ : jaa (.) jaa (.) vot kui kahe- (.) peale kahekümnendat aprilli ma sõidan (..) mind viidakse sinna suvilasse 1 N76 Vn 'Pesin nõusid, /pesin põrandaid/ (..) kohvik/seal on see nuka peal metroo juures (.) kohvik-piimasaal (.) ja seal ma siis töötasin, nõudepesijana, koristajana ja kellena veel (..) talvel töötan, kevadel lähen ära (.) talvel töötan (.) kevadel lähen ära (..) Mul oli vaja raha suvila ehitamise jaoks.'

Keelevahetus on selles situatsioonis sujuv, võimalik, et kõnelejale ka märkamatu, ning kestab seni, kuni järgmises repliigis eesti keelt kõnelev kaasvestleja ta „kokkuleppe” juurde tagasi toob. Edasi jätkub vestlus eesti keeles. Selliseid keelevahetusjuhtumeid, kus keelejuht läheb üle pikemale venekeelsele monoloogile, tuleb samas intervjuus ette korduvalt.

Niisugune sujuv vene keelele üleminek on iseloomulik nn vanemale, põliste Peterburi eestlaste põlvkonnale; nõukogude võimu ajal Peterburi elama asunute keeles selliseid spontaanseid üleminekuid siinsetes lindistustes ei esine.

Väga tüüpiline näide koodivahetusest on tsiteerimine ja refereerimine (Gumperz 1982: 75-76). Tsiteerides või refereerides kellegi kolmanda isiku sõnu, on lisaks sõnumi edastamisele koodivahetuse ülesanne ka edastada ütleja arvamust ja selle tähtsust rõhutada (Praakli 2007: 155).

Näites 2 kirjeldab keelejuht instituuti astumist pärast üheksaklassilise kooli lõpetamist aastal, kui Nõukogude Liidu koolides mindi üle kümneklassilisele keskharidusele. Tolle üleminekuaasta 9. klassi lõpetanud võisid astuda kõrgkooli või jätkata õpinguid 10. klassis. Koodivahetusel on selles vestluse katkendis kindel funktsioon: sündmuse kulminatsiooni rõhutamine. Sündmust kirjeldatakse kaht eri ajal ja eri kohas toimunud dialoogi vahendades, jutustuse põhikeeleks on eesti keel. 
(2)

mina läksin kõik eksamid viiedega läbi (.) ja mind juba (.) no kutsutakse instituuti (..) aga tooge midagi dokumenti (.) kus te enne õppisite (..) mina lähen kooli (.) ja direktor mulle ei anna (..) Sina pead tulema kümnendasse klassi (..) > vy gordost' našei školy (..) kak ja mogu vas otpustit' (..) Ma ütlen (.) menja uže začisljaet v institut (..) < ja ta siis kirjutas niisukese paberi (.) et mind just ei võta vasta $1 \mathrm{~N} 92$

Vn ..'te olete meie kooli uhkus (..) kuidas ma saan teid minema lasta...' '/Ma ütlen/ (.) mind võeti juba instituuti vastu (..)'

Jutustuse esimeses osas vahendab keelejuht instituudi ametnikku, kes palus tuua koolist mingi dokumendi seal õppimise kohta (aga tooge midagi dokumenti, kus te enne õppisite). Sündmuse arengut koolis kirjeldab keelejuht direktori öeldut tsiteerides ja refereerides. Toodud on kaks lauset, millest teine on venekeelne. Tegelikult on mõlemad vestlused, nii instituudis kui ka keskkoolis, toimunud vene keeles. Siit nähtub, et sündmuse olulisem osa on just see jutuajamine, ning selle kahekõne olulisema osa esitab ta selle toimumise keeles. Nii soovib ta rõhutada koolidirektori ranget seisukohta, mida omakorda rõhutab valjem hääletoon (litereeritud lõigus paigutatud märkide $><$ vahele).

Sellist mingi lähemas või kaugemas minevikus toimunud sündmuse pingeid edastavat koodivahetust esineb ühtviisi nii põliste kui ka hiljem sisserännanud eestlaste keeles. Näites 3 kirjeldab teise eestlaste rühma kuuluv keelejuht juhtumit haiglas, kus ta oli tuttavale tugiisikuks. Kui alguses antakse suhteliselt rahulikult alanud dialoogi oletatavasti noore arstiga edasi eesti keeles, siis pinge kasvades toimub keelevahetus, keelejuht tsiteerib vestluspartnerit (arsti) vestluse toimumise keeles.

Ma küsin selle poisi käest, et kas ei ole mingisugust rohtu anda.. No mi(s) me peame talle siis andma. Ma üt(le)sin 
(.) et midagi (.) et inimesel parem oleks (..) sis (.) ot ètogo nekto ne umiraet $2 \mathrm{~N} 71$

Vn 'sellesse ei sure keegi'

Teadliku koodivahetuse kui tähtsaima tekstiosa edastamise võtte leiab ka näiteks K. Praakli Tampere eestlaste koodivahetusjuhtumite kirjeldusest (Praakli 2007: 155 ja 2009: 89-90).

Intervjuude küsimuste-vastuste vorm on Peterburi keelejuhtide keelenäidete salvestamisel olnud üsna paindlik. Intervjueerija pole vestlust rangelt suunanud ja vastajad on saanud rääkida neile meelepärastel teemadel. Sündmuste kirjeldamisel või olulise sõnumi vahendamisel on kõneleja tahtnud anda oma sõnadele ka emotsionaalset värvingut. Selleks on keelejuhi arvates sobinud vanasõnad või kõnekäänud, mida tsiteeritakse originaalkeeles, nagu nähtub ka näitest 4 :

kümnendal mail saan ma üheksakümmend kaks aastat (.) kui elan selleni (..) sellepärast (.) et kak gavaritsja (..) my predpologaem (.) a bog raspologaet (1N92)

Vn 'nagu öeldakse (..) meie otsustame (.) aga jumal juhib'

Sellisele kujundi lisamisele ja keelevahetusele eelneb ka saatelause kak gavaritsja 'nagu öeldakse', kuid keelevahetus ise on loomulik ja sujuv, ilma spetsiifilise märguandeta.

Eespool esitatud juhtumitest võiks järeldada, et vene keelt kasutatakse sündmuse eheduse ja ilmestamise ning mõistete täpsuse edastamiseks. Näites 5 annab keelejuht märku soovist üle minna vene keelele, uurides, kas vestluspartner temast aru saab:
K:.. nu vot a Gatčinas oli see koht kus (.) oli keisri ema (..) see oli nagu (..) te vene keelt hästi valdate?
I: no natukene
$\mathrm{K}$ : see oli nagu pridvornyi gorod $1 \mathrm{~N} 92$
Vn 'õukonnalinn' 
Peterburi lähistelt pärit eakas keelejuht kirjeldas oma kodulinna Gattšinat kui Vene keisrinna suvituslinna; vestluses meenutas ta sageli oma vanaema, kelle mälestuste temaatika sageli Vene õukonna elu puudutas. Võib oletada, et üleminekuga vene keelele rõhutas ka keelejuht nii lugupidamist tsaari perekonna vastu kui ka vanaema mälestuste tähtsust.

Koodivahetust sotsiolingvistilisest vaatenurgast kirjeldanud Carol Myers-Scotton märgib, et valides ühe keele, seob mitmekeelne kõneleja end ühe identiteediga ja võtab seega endale ka mingid sellega seonduvad sotsiaalsed õigused ja kohustused (Myers-Scotton 1988, viidatud Kalliokoski 1995: 5 kaudu). Näites 6 kirjeldab keelejuht nõukogude ajal hävitatud surnuaeda; oma taunivat suhtumist kalmistu hävitamisse näitab ta koodivahetusega.

praegu see surnuaed kadunud (.) sõja aeg temast tehti no (.) üks- (..) pandi need betooni- (.) betonnye plity (..) $>$ delali avtoremontnye masterskie (..) < no ühesõnaga inimeste kontide peale panivad kõik $1 \mathrm{~N} 92$

Vn 'betoonplaadid (..) tehti autoremondi töökoda'

Tsitaadi toon ja sõnastus näitab, et kõneleja vahendab oma negatiivset elamust seoses kalmistu hävitamisega. Mitu uurijat on näinud koodivahetuses ka kõneleja hoiaku muutuse keelelist väljendust (Gumperz 1982: 80, Kalliokoski 1995: 9), nt enese distantseerimist mingist arvamusest, mis ei lange kokku kõneleja enda omaga. Näites 6 ei ole tsitaadile viitavat saatelauset, ent ka selles esinevat koodivahetust võib tõlgendada kontekstivihjena: üleminekuga vene keelele annab keelejuht märku oma hukkamõistvast hoiakust toimunu suhtes. Teadlikust koodivahetusest annab märku sõnakordus betooni-koodivahetusliku lause ees, mida võib tõlgendada ka koodivahetusele iseloomuliku korduse või nn vale algusena, kus lauset alustati „,vales” keeles ja teisele keelele üle minnes korratakse öeldut (vt ka Kovác 2001: 119, Praakli 2007: 155). 


\subsection{Koodivahetus kui suhtlemist abistav vahend}

Koodivahetuse võib vestluses esile kutsuda ka kõneleja suutmatus end ühes keeles arusaadavalt väljendada. Teisele keelele üleminekuks piisab takistusest sobiva sõna või ka pikema väljendi leidmisel. Näiteks vestluses sellest, kuidas eestlaste seltsielu Peterburis 1990. aastatel käivitus, nendib kakskeelsest perest pärit ja Peterburis üles kasvanud keelejuht, et oma arvamuse väljendamiseks jääb eestikeelseid sõnu puudu (kuidas ütelda...) ning läheb teadlikult üle vene keelele (7):

aga nagu (.) kuidas ütelda.. èstontsy raskačivali(s)' dolgo (.) vot (.) no za to osnavatel'no... $2 \mathrm{~N} 52$

Vn 'eestlased võtsid hoogu kaua (.) aga see-eest põhjalikult'

Niisugust üleminekut vene keelele tuleb ette sagedamini põlistel Peterburi eestlastel, kelle jaoks on teatud teemadel (nt ülaltoodud Peterburi eestlaste seltsielu algusaastad) lihtsam end vene keeles väljendada ja keelevahetus tundub kindlam viis soovitut edasi anda. Hilisematel sisserännanutel, kes on saanud hariduse Eestis eestikeelses koolis, selliseid takistusi peaaegu ei esine, küll aga nendel, kes on õppinud venekeelses koolis.

Suulises kõnes (vestluses) tuleb kõnelejal ette kahesuguseid takistusi (Hennoste ja Vihalemm 1999: 1574): kõnetempost johtuvalt ei jõua ta alati teha järgnevat teksti rahuldavalt valmis ja peab seetõttu valikuid edasi lükkama; mitmesugustel põhjustel peab kõneleja oluliseks ka juba väljaöeldud lausungit ümber sõnastada. Emakeelse suhtluse uurimisel nimetatakse konversatsioonianalüüsis selliste probleemide lahendamise võtteid parandusmehhanismiks, mida saab hõlpsasti laiendada ka võõrkeele suhtlusstrateegiate kirjeldamisele (Hennoste ja Vihalemm 1999: 1602, Pool ja Kikerpill 2003: 50 ja Kalliokoski 1995: 6).

Võõrkeele kõnelejal on Tiit Hennoste ja Triin Vihalemma järgi kaks põhiprobleemi (1999: 1583-1584), mis loovad aluse suhtlusstrateegiate rakendamiseks: kõneleja vajab oma teksti moodustamiseks rohkem aega ja sagedamini esineb vajadus 
otsida sobivat väljendit või sõnavormi. Probleemile lahendust otsides võib kõneleja paluda otsesõnu abi vestluspartnerilt või lausungi reformuleerida, kuid lahenduseks võib olla näiteks ka tõlge või koodivahetus (Hennoste ja Vihalemm 1999: 1595). Suhtlusstrateegiaks loevad Vihalemm ja Hennoste teksti pinnal toimuvat protsessi; seejuures on oluline, et kõneleja annab märku strateegia algatamisest, lahendab olukorra, strateegial on mingi tulemus ja sellele võivad järgneda kommentaarid. Strateegiad võivad seejuures olla monoloogilised või dialoogilised, st selle elluviijaks on esimesel juhul üks ja sama isik või teisel juhul vestluspartnerid koostöös.

Muukeelsete üliõpilaste suhtlusstrateegiaid uurinud Tiina Kikerpill ja Raili Pool (2003: 59) nimetavad samuti koodivahetuslikke strateegiaid üheks suhtlust organiseerivaks ja abistavaks vahendiks. Ka kuulub keeleõppija strateegiate hulka enese öeldu parandamine ja reformuleerimine koodivahetuslike võtetega.

Ehkki Peterburi eestlased püüavad nendes intervjuudes rääkida oma emakeelt, tuleb vestluses ette keeleõppija omadega sarnaseid takistusi, mis sunnivad neid vestluskaaslaselt abi ja öeldule kinnitust otsima või öeldut parandama. Üleminek vene keelele on loomulik, sest tuge otsitakse sellest keelest, milles end selles olukorras kindlamalt tuntakse.

\subsubsection{Koodivahetuslikud abiotsimise strateegiad}

Venekeelses keskkonnas saavad Peterburi eestlased lapsepõlves omandatud eesti keelt rääkida suhteliselt harva; paljudele pole kättesaadavad ka Eesti elektroonilised teabekanalid ega trükimeedia. Nende eesti keele kasutamine on taandunud ja eestikeelsel suhtlemisel tekib võõrkeele kõnelejaga sarnaseid probleeme. Enamasti otsitakse kinnitust või abi oma lausungile, probleemse sõna või väljendi juures minnakse üle vene keelele. Näidetes 8-11 rakendavad keelejuhid teadlikult koodivahetust abiotsimise strateegiana, mida väljendatakse näites 8 otsese küsimusega (kuidas see on?) või püütakse samas näites vestlus- 
partnerit ärgitada talle sobivat väljendit pakkuma (no mitte trü$k i b, a)$.

K: luule- (.) luuletused (..) niizukesed /õ-õ/ noh /õ/ (.) kuidas see on see (.) ljubiteli

I: harrastus?

$\mathrm{K}$ : harrastuseluuletused (.) jah 1N86

(9)

$\mathrm{K}$ : kes neid raamatuid /õõ/ trük- no mitte trükib, a-

I: koostab?

K: izdä̈t

I: välja annab

$\mathrm{K}$ : välja annab /naer/ nu vot $1 \mathrm{~N} 86$

Näites 8 püüab keelejuht koodivahetust edasi lükata ja kasutab venekeelset sõna alles siis, kui vestluspartner tema jaoks sobivat sõna ette ei öelnud.

Näites 10 kasutab keelejuht koodivahetust ka küsimuse vormistamisel (kak ne zakončila); eestikeelse vaste leidmisel kordab järgmises kõnevoorus kuuldut ja lisab uue koodivahetusliku elemendi (aspirantura), millest võib aga oletada, et kõneleja peab seda eestikeelseks sõnaks. Kõikidel juhtudel kordavad keelejuhid vestluspartnerilt kuuldud vastust.
$\mathrm{K}$ : ma ei (.) noh kak ne zakončila
I: ei lõpetanud
$\mathrm{K}$ : ei lõpetanud aspirantura $1 \mathrm{~N} 35$

Eeltoodud kolmest näitest nähtub, et koodivahetus on teadlik ja planeeritud ning keelejuht eeldab vestluspartnerilt vene keele oskust. Enamikul juhtudel eelneb koodivahetusele iseloomulik paus, nagu näidetes $8 \mathrm{ja} 10$, mis on märguanne keele vahetuse kohta. 
Mõnikord jääb keelejuht koodivahetuse juures kõhklema, arvatavasti kaheldes ka vestluspartneri vene keele oskuses, nagu on näha näitest 11. Siingi eelneb koodivahetuslikule ümberlülitusele lühike paus ja lausung lõpeb samuti pausiga, ootuses, et vestluspartner ütleb sobiva väljendi. Sarnaselt eespool kirjeldatud koodivahetussituatsioonidega kordab keelejuht kuuldut ja jätkab pooleli jäänud teemal.
K: oli niisukene (.) nepolnaja srednjaja škola nimetati
I: mittetäielik keskkool
$\mathrm{K}$ : njaa (.) mittetäielik keskkool 1N86

Harvem esineb ümberlülitust, millele järgneb abiotsiv küsimus, nagu on näha näitest 12 . Keelejuht hakkab kahtlema kasutatud väljendi õigsuses ning otsib vestluspartnerilt küsimusega kinnitust.

I: Mida sa seal tegid?

K: Ma olin kanstruktor. On? (.) ma ei tea (.) eesti keeles (.) on?

I: konstruktor $1 \mathrm{~N} 67$

Tõenäoliselt annab siin kõnelejale julgust sõna eesti keele võõrsõna konstruktor, mis vene keeles erineb vaid häälduse poolest (kanstruktor). Internatsionalismid on üks sõnaderühm, milles ilmneb kõige paremini kahe kontaktsituatsiooni sattunud keele lähenemine ehk konvergents. Seesugust kahe morfoloogiliselt tüübilt erineva keele foneetilist lähenemist on täheldatud ka näiteks Eesti vene üliõpilaste keelekasutuses, kus venekeelses vestluses esinevate võõrsõnade rõhk ja foneemide realisatsioon on eestipärane (Zabrodskaja 2006: 740). Peterburi eestlaste eesti keele kasutuses on märgata sama tendentsi võõrsõnade puhul, millel on sarnane päritolu mõlemas keeles. 


\subsubsection{Koodivahetuslik reformuleerimine}

Loomuliku vestluse käigus võib kõneleja leida, et tema väljaöeldud lausungis on midagi valesti, ja ta soovib seda parandada. Toimub reformuleerimine, millega kõneleja püüab leida teist väljendit, öeldut kustutada, täiendada või välja vahetada (Hennoste ja Vihalemm 1999: 1592). Võõrkeele õppijatel on koodivahetus üks tavalisemaid asendusstrateegiaid kõnes tekkinud lünga täitmiseks (Dörnyei ja Kormos 1998: 363). Ka kakskeelsed kõnelejad kasutavad sama võtet puuduva sõna asendamiseks. Näites 13 otsib keelejuht vajalikku sõna, kuid pole kindel kasutatud sõna sobilikkuses ja vahetab keelt oma mõttekäigu täpsustamiseks.

Nõnna et sis ta õppis seal (.) kuda ta (.) kaugelõpetus (.) vot zaočnyi vot (.) no ühesõnaga tegi kodu need ülesanded ära $1 \mathrm{~N} 92$

Vn 'kaugõpe'

Siin on näha ka teisi eespool nimetatud koodivahetust märgistavaid elemente: pause ümberlülituse ees, kordust (kaugelõpetus) ja reformuleerimist (ühesõnaga tegi kodu need ülesanded ära).

Sarnast võtet kasutavad ka keeleõppijad (vt Kikerpill ja Pool 2003: 91). Eelnevas näites rakendab kõneleja esmalt otsimisstrateegiat ( $k u d a t a)$, seejärel meenub eestikeelne (esialgu ebatäpne) vaste ja sõnumi arusaadavuse kinnitamiseks kasutab kõneleja ka koodivahetust.

\section{Koodivahetus või laen}

Koodivahetust peetakse keelekontaktide kõige põhilisemaks ja markantsemaks mehhanismiks (Verschik 2010: 161), samas on see leksikaalsete laenude vahendaja. Sotsiolingvistilisest ja grammatilisest vaatenurgast lähtuvate uurijate huvi 
keskendub seetõttu ka laenamisele, selle mehhanismidele, piirangutele ja hierarhiatele ning koodivahetuse ja leksikaalse laenu vahekorra selgitamisele (lähemalt Verschik 2007: 357-377, 2010: 143-175 ja Kokko 2007: 34). Carol Myers-Scotton (2001) pakub välja maatrikskeele raamistiku mudeli, mis lähtub sellest, et keelte osalus vestluses pole võrdne, vaid üks on põhikeel ehk maatrikskeel, teine sisendkeel. Maatrikskeelde võetakse sisendkeelest pärit tüved, millele liituvad maatrikskeelest pärit morfeemid, nagu näites 14, kus vene kõnekeelsele sõnale probka 'ummik' on liidetud mitmuse tunnus ja käändelõpp.

kui ei ole tee peal neid vene keeles propkasid (.) siis buss läheb nelikümmend minutit 1M78

Vn 'liiklusummik'

Maatrikskeele mudel võimaldab ka integreerimata tüvesid, mis Myers-Scottoni järgi on siiski haruldane (Myers-Scotton 2001: 27-28), vt näited 8 ja 14. Niisuguste tühjade vormide esinemise tõlgendamine on probleemne, millele on tähelepanu juhtinud ka K. Praakli (2009: 51). Ootuspäraselt tühjade vormidena esinevad elemendid nt omastavas käändes, millel eesti keeles puudub morfoloogiline tunnus. Keerulisem on integreerumata elementidega. Näites 15 esineb väljend častnaja sobstvennost' mõlemal korral nominatiivis, mis lausungi esimeses osas on morfosüntaktiliselt korrektne, kuid lause teises pooles oleks ootuspärane kasutada eesti partitiivi (ei tohtinud olla častnaja sobstvennosti).

meil oli častnaja sobstvennost' (.) a ei tohtinud olla častnaja sobstvennost' $1 \mathrm{~N} 82$

Vn 'eraomand'

Kõnealuses näites on tegemist ühe keelejuhi individuaalse keelekasutusega, venekeelse väljendi kasutamine siin on juhuslik ja ajutine, pole mingit kinnitust väljendi põlistumi- 
sele ega sellele, et seesugust keelendit esineks teiste keelejuhtide kõnes.

Ühesõnalise koodivahetuse liigitamisel laenuks on toodud mitu kriteeriumi, morfosüntaktilist ja fonoloogilist integratsiooni ning põlistumist keelekogukonnas. Näiteks Ameerika eesti keele analüüsis loeb Anna-Liisa Ševeljova (2009) eestipärase hääldusega elemendi laenuks, inglispärase hääldusega koodivahetuseks (viidatud Kivik 2010: 220 kaudu).

Keeruline on otsustada ka uue elemendi põlistumist, sest laenamine võib olla juhuslik ja sujuv, nagu on näha näitest 16 . Lausungi esimeses osas kasutab keelejuht venekeelset sõna $k a r t o c ̌ k a+d$ ja lausungi lõpus eestikeelset kaardid. Tegemist on planeerimata koodivahetusega, kõnetempo ja üleminek teisele keelele on sujuv ja pausideta. Automaatsele lahendusele viitab venekeelses sõnas eesti mitmuse tunnuse $-d$ kasutamine vene sõnas.

A see räägib, et /--/ koolis käid (..) kartočkad olid (.) et las ma lähen kunstikooli óppima (.) sääl ma saan suuremad kaardid. $1 \mathrm{~N} 87$

Vn 'kaardid'

Seesugust kiiret koodivahetust suhtluse uurijad Hennoste ja Vihalemm (1999: 1582) võõrkeele suhtlusstrateegiate hulka ei loe, nende arvates pole tegemist probleemi lahendamisega, vaid keelekasutuse veaga, kõrvalekaldega või kõneleja suutmatusega. Eesti-ingerisoome kakskeelsust uurinud Helka Riionheimo (2010) selgitab, et keelesüsteemide piirid on hägusad ja meil pole kindlat seletust selle kohta, kuidas kulgevad keelte piirid kakskeelse inimese kõnes. Kakskeelse kõneleja käsutuses on mitmesugused keelelised vahendid, mida ta võib loovalt kasutada, ning lõpptulemus ei pruugi olla sarnane ükskeelse kõneleja standarditega (Verschik 2010: 163). Seetõttu pole uurijate meelest otstarbekas teha ranget vahet koodivahetuse ja laenude vahel, vaid käsitleda kahe keele vahelduvat kasutamist üldisemalt, ühe keele elementide kopeerimisena teise keele konteksti 
(Riionheimo 2010: 231, pikemalt nt Verschik 2007: 365-377 ja Praakli 2009).

Samas pole täit kindlust, kas eespool toodud näidetes 14-16 esinenud leksikaalsed elemendid on muutunud kogukonnas üldkasutatavateks laenudeks; pigem võib oletada, et tegemist on idiolektide nähtusega.

\section{Kokkuvõte}

Peterburi vanema põlvkonna eestlaste keelematerjali põhjal võib öelda, et koodivahetust esines kõigi kümne põlise Peterburi eestlase jutustustes. Salvestatud materjali hulgas torkab silma kultuurispetsiifiliste laenude hulk - 38, millest enamik on seotud kõneleja haridustee ja tööeluga, osa pärineb igapäevaelu üldisematest kirjeldustest. Teadlik vene keelele üleminek on siin ootuspärane, kui keelejuht ei tea eesti vastet või soovib olla mõistetes täpne.

Väga olulisel kohal on koodivahetus kontekstualiseerimise vahendina. Mingit sündmust või juhtumit kirjeldades lülitub keelejuht vene keelele tsiteerimisel ja refereerimisel (vaadeldud materjalis 19 korral), kui püütakse võimalikult täpselt tuntud sõnumit ja arvamust edasi anda (kolm juhtumit, kus keelejuht nimetas vanasõna või kõnekäändu), samuti mingi seiga kirjeldamisel, kui on tarvis vestluspartnerit enda hoiakust teavitada (kaks juhtumit, kus venekeelse tsitaadiga väljendas keelejuht kellegi hoiakut, mis tema arvamusega kokku ei langenud).

Eesti keele igapäevase kasutuse vähenemine soosib keele unustamist, seetõttu otsivad keelejuhid vestluspartnerilt tuge koodivahetuslike võtete abil. Harvem väljendas keelejuht oma ebakindlust ja kontrollis sõna või väljendi õigsust (vaadeldud materjalis kaheksal korral), pigem küsiti intervjueerija abi ununenud sõnale vaste leidmiseks (12 korral) .

Loomulikus vestluses esineb mitmesugust laadi ümberlülitust teisele keelele, sageli on tegemist ühesõnalise koodivahetusega. Et ühesõnalise koodivahetuse ja leksikaalse laenu eristamine on keeruline, taandub selliste juhtumine tõlgenda- 
mine üksikisiku keele analüüsile või konkreetsele suhtlussituatsioonile.

\section{Aadress:}

Lea Jürgenstein

Eesti ja üldkeeleteaduse instituut

Tartu Ülikool

Jakobi 2

51004 Tartu, Eesti

E-mail: leastein@suomi24.fi

\section{Kirjandus}

Auer, Peter (1992) “Introduction: John Gumperz's approach to contextualization." In P. Auer and Aaldo di Luzio, eds. The contextualization of language, 1-38. Amsterdam: Benjamins.

Allik, Mari (2002) Lõuna-Rootsi noored eestlased: nende keel ja identiteet. Käsikirjaline magistritöö. Tartu: Tartu Ülikool. Eesti keele (võõrkeelena) osakond.

Dörnyei, Zoltan and Judit Kormos (1998) "Problem-solving mechanisms in L2 communication. A psyholinguistic perspective". Studies in Second Language Acquisition 20, 349-385.

Gumperz, John (1982) Discource strategies. Studies in international sociolinguistics 1. Cambridge: Cambridge University Press.

Haugen, Einar (1953) The Norwegian language in America: a study in bilingual behaviour. Bloomington: Indiana University Press.

Hennoste, Tiit ja Triin Vihalemm (1999) „Võõrkeele suhtlusstrateegiad”. Akadeemia 8, 1571-1607.

Hennoste, Tiit (2003) „Keelekasutuse uurimine”. Emakeele Seltsi aastaraamat 48, 217-262.

Jürgenstein, Lea ja Liina Rootalu (2011) Peterburi eestlaste lood. Tallinn: Ajakirjade Kirjastus.

Kalliokoski, Jyrki (1995) „Koodinvaihto ja keskustelun moniäänisyys”. Virittäjä 99, 2-24.

Kessel, Tiia (1981) Ülevaade Kaukaasia eestlaste keelest. Käsikirjaline diplomitöö. Tartu: Tartu Ülikool. Eesti keele osakond.

Kikerpill, Tiina ja Raili Pool (2003) „Muutused eesti keele teise keelena kõnelejate suhtlusstrateegiate kasutuses ühe aasta jooksul". Lähivertailuja 13, 50-60.

Kivik, Piibi-Kai (2010) „Eestlased ja eesti keel Ameerika Ühendriikides”. Raamatus Kristiina Praakli ja Jüri Viikberg, toim. Eestlased ja eesti keel maailmas, 195-238. Tallinn: Eesti Keele Sihtasutus. 
Kokko, Ossi (2007) Inkerinsuomen pirstaleisyys. Eräiden sijojen kehitys murteen yksilöllistymisen kuvastajana. Joensuun yliopiston humanistisia julkaisuja No 48. Veebis <http://joypub.joensuu.fi/publications/dissertations/kokko_inkerinsuomen/kokko.pdf>. Vaadatud 10.05.2011.

Kovács, Magdolna (2004) „Australiansuomalaiset kielenvaihdon kynnyksellä”. Virittäjä 2, 200-223

Kulu, Hill (1992) Eestlased maailmas. Ülevaade arvukusest ja paiknemisest. Tartu: Tartu Ülikool.

Lauttamus, Timo (1992) „Lainaaminen ja koodinvaihto: havaintoja amerikansuomalaisten kielistä’. Virittäjä 1, 3-16.

Mahtina, Veronika (2008) Eesti Jaani kirik Peterburis. Tallinn: Peterburi Jaani Kiriku Fond.

Moosberg, Hilda (1989) Neevalinnast Emajõelinna. Tallinn: Eesti Raamat.

Myers-Scotton, Carol (1988) "Codeswitching as indexical of social negotiations". In Monica Heller, ed. Codeswitching. Anthropological and sociolinguistic perspectives, 151-186. Berlin: Mouton de Gruyter.

Myers-Scotton, Carol (2001) "The matrix language frame model: Developments and responses". In Rodolfo Jakobson, ed. Codeswitching worldwide II, 23-58. (Trends in Linguistics. Studies and Monographs, 126.) Berlin, New York: Mouton de Gruyter,

Nigol, August (1918) Eesti asundused ja asupaigad Wenemaal. Tartu. Veebis $<$ http://www2.kirmus.ee/grafo/index.php?gid=4>. Vaadatud 28.03.2010.

Pérez Casas, Marisol (2008) Codeswitching and identity among island Puerto Rican bilinguals. A dissertation submitted to the Faculty of the Graduate School of Arts and Sciences of Georgetown University in partial fulfillment of the requirements for the degree of Doctor in Philosophy in Spanish Linguistics. Veebis <http:/gradworks.umi.com/3341614. pdf $>$. Vaadatud 14.02.2012.

Praakli, Kristiina (2007) „Mõnda eesti-soome koodivahetuse funktsioonidest ja nende tõlgendamisvõimalustest”. Raamatus Raili Pool, toim. Emakeel ja teised keeled V, 151-163. (Tartu Ülikooli eesti keele (võõrkeelena) õppetooli toimetised, 6.) Tartu: Tartu Ülikooli Kirjastus.

Praakli, Kristiina (2009) Esimese põlvkonna Soome eestlaste kakskeelne keelekasutus ja koodikopeerimine. (Dissertationes Philologiae Estoniae Universitatis Tartuensis, 24.) Tartu: Tartu Ülikooli Kirjastus.

Pullat, Raimo (2004) Lootuste linn Peterburi ja eesti haritlaskonna kujunemine kuni 1917. Tallinn: Estopol.

Raag, Raimo (1982) Lexical characteristics in Swedish Estonian. (Acta Universitatis Upsalaensis. Studia Uralica et Altaica Upsaliensia, 13.) Uppsala.

Raag, Raimo (1999) Eestlane väljaspool Eestit. Tartu: Tartu Ülikooli Kirjastus.

Riionheimo, Helka (2010) „Morfologinen limittyminen suomen ja viron kontaktissa”. Lähivertailuja 19, 218-239. 
Roos, Aarand (1980) Morfologiska tendenser vid språklig interferens med estniska som bas. (Acta Universitatis Upsaliensis. Studia Uralica et Altaica Upsaliensa, 12.) Uppsala.

Sarhimaa, Anneli (1999) Syntactic transfer, contact-induced change, and the evolution of bilingual mixed codes: focus on Karelian-Russian language alternation. (Studia Fennica, Linguistica, 9.) Helsinki: Finnish Literature Society.

Ševeljova, Anna-Liisa (2004) USA eestlaste koodivahetus. Käsikirjaline seminaritöö. Tallinn: Tallinna Ülikool. Eesti keele ja kultuuri instituut.

Zabrodskaja, Anastassia (2005) Vene-eesti koodivahetus Kohtla-Järve vene emakeelega algkoolilastel. (Tallinna Ülikooli eesti filoloogia osakonna toimetised, 6.) Tallinn: TLÜ Kirjastus.

Zabrodskaja, Anastassia (2006) „Eestivene keel(evariant): kas samm segakoodi poole?" Keel ja Kirjandus 9, 736-750.

Zabrodskaja, Anastassia (2009) Russian-Estonian language contacts: grammatical aspects of language use and change. Analytical overview. Tallinn: TLÜ Kirjastus

Teral, Maarika (2007) Taani eestlaste keelest. Magistritöö. Tartu: Tartu Ülikool. Eesti ja üldkeeleteaduse instituut. Veebis $<$ https://dspace.utlib.ee/ dspace/bitstream/handle/10062/2868/teralmaarika.pdf?sequence=1>. Vaadatud 02.07.2012.

Verschik, Anna (2004) „Koodivahetus meil ja mujal”. Keel ja Kirjandus 1, 25-46.

Verschik, Anna (2007) „Keelekontaktid, laenatavus ja verbi kopeerimine eestivene keelevariandis". Keel ja Kirjandus 5, 357-377.

Verschik, Anna (2010) „Keelekontaktid ja kontaktidest johtuvad keelemuutused”. Raamatus Kristiina Praakli ja Jüri Viikberg, toim. Eestlased ja eesti keel välismaal, 143-175. Tallinn: Eesti Keele Sihtasutus.

Viikberg, Jüri (1989) „Koodivahetus ja Siberi eestlased. Lähtekohti”. Keel ja Kirjandus 4, 202-205.

Viikberg, Jüri (1997) „Eesti külad Venemaal: keel ja identiteet”. Raamatus H. Kulu, K. Metsis ja T. Tammaru, toim. Eestlane olla... Eesti keele ja kultuuri perspektiivid, 28-52. Tartu: Tartu Ülikooli Kirjastus.

Viikberg, Jüri ja Lembit Vaba (1984) „Siberi põhjaeestlasi kõnetamas”. Keel ja Kirjandus 3, 145-156 ja 4, 210-223.

Weinreich, Uriel (1953) Languages in contact: findings and problems. The Hague: Mouton.

Abstract. Lea Jürgenstein: Code-switching in the language use
of older-generation Estonians living in St. Petersburg. The article
focuses on the language use of older-generation Estonians living in St.
Petersburg. The author's aim is to describe code-switching, its func-
tions and occurrence in conversations involving a monolingual Esto-
nian. Code-switching in such conversations plays a metaphoric role, 
allowing speakers to signal their attitudes. On the other hand, codeswitching may also appear as a communication strategy used by language informants to solicit cues from the collocutor to retrieve a word they have forgotten, to avoid conscious code-switching or to specify what they have said. Since code-switching is an important channel for lexical loans, the article examines the relationship of single-word and multi-word code-switching and loans.

Keywords: diaspora, borrowing, communication strategy, bilingualism, Estonian 
